University of Nebraska - Lincoln

DigitalCommons@University of Nebraska - Lincoln

\title{
Visualization of Biomass Solubilization and Cellulose Regeneration During lonic Liquid Pretreatment of Switchgrass
}

\author{
Seema Singh \\ Joint BioEnergy Institute \\ Blake A. Simmons \\ Joint BioEnergy Institute, BASimmons@lbl.gov \\ Kenneth P. Vogel \\ University of Nebraska-Lincoln, kvogel1@unl.edu
}

Follow this and additional works at: https://digitalcommons.unl.edu/usdaarsfacpub

Part of the Agricultural Science Commons

Singh, Seema; Simmons, Blake A.; and Vogel, Kenneth P., "Visualization of Biomass Solubilization and Cellulose Regeneration During lonic Liquid Pretreatment of Switchgrass" (2009). Publications from USDAARS / UNL Faculty. 395.

https://digitalcommons.unl.edu/usdaarsfacpub/395

This Article is brought to you for free and open access by the U.S. Department of Agriculture: Agricultural Research Service, Lincoln, Nebraska at DigitalCommons@University of Nebraska - Lincoln. It has been accepted for inclusion in Publications from USDA-ARS / UNL Faculty by an authorized administrator of DigitalCommons@University of Nebraska - Lincoln. 


\title{
Visualization of Biomass Solubilization and Cellulose Regeneration During Ionic Liquid Pretreatment of Switchgrass
}

\author{
Seema Singh, ${ }^{1,2}$ Blake A. Simmons, ${ }^{1,2}$ Kenneth P. Vogel ${ }^{3}$ \\ ${ }^{1}$ Joint BioEnergy Institute, Deconstruction Division, Emeryville, California; \\ telephone: 925-337-6154; fax: 925-294-3020; e-mail: basimmo@sandia.gov \\ ${ }^{2}$ Sandia National Laboratories, Biomass Science and Conversion Technology Department, \\ Livermore, California \\ ${ }^{3}$ United States Department of Agriculture, Grain, Forage and Bioenergy Research Unit, \\ USDA-ARS, University of Nebraska, Lincoln, Nebraska
}

Received 4 March 2009; revision received 17 April 2009; accepted 27 April 2009

Published online 4 May 2009 in Wiley InterScience (www.interscience.wiley.com). DOI 10.1002/bit.22386

\begin{abstract}
Auto-fluorescent mapping of plant cell walls was used to visualize cellulose and lignin in pristine switchgrass (Panicum virgatum) stems to determine the mechanisms of biomass dissolution during ionic liquid pretreatment. The addition of ground switchgrass to the ionic liquid 1-n-ethyl-3-methylimidazolium acetate resulted in the disruption and solubilization of the plant cell wall at mild temperatures. Swelling of the plant cell wall, attributed to disruption of inter- and intramolecular hydrogen bonding between cellulose fibrils and lignin, followed by complete dissolution of biomass, was observed without using imaging techniques that require staining, embedding, and processing of biomass. Subsequent cellulose regeneration via the addition of an anti-solvent, such as water, was observed in situ and provided direct evidence of significant rejection of lignin from the recovered polysaccharides. This observation was confirmed by chemical analysis of the regenerated cellulose. In comparison to untreated biomass, ionic liquid pretreated biomass produces cellulose that is efficiently hydrolyzed with commercial cellulase cocktail with high sugar yields over a relatively short time interval.

Biotechnol. Bioeng. 2009;104: 68-75.

Published 2009 Wiley Periodicals, Inc.
\end{abstract}

KEYWORDS: biofuels; biomass; ionic liquids; pretreatment

\section{Introduction}

Lignocellulosic biomass is a relatively low cost feedstock for biofuels production (Gallezot, 2008; Gomez et al., 2008), with the potential of being cost competitive with fossil fuels on an equivalent energy content basis (Demirbas, 2008;

Correspondence to: B.A. Simmons

Additional Supporting Information may be found in the online version of this article.
Sierra et al., 2008). It is reported that there is a significant amount of biomass available for conversion into biofuels on a renewable basis to displace a significant portion of the fossil fuels currently consumed within the transportation sector (Simmons et al., 2008). New approaches are required to reduce costs of a cellulosic biofuels to be competitive with conventional products derived from petroleum (Lynd et al., 2008). Lignocellulose must be pretreated prior to addition of hydrolytic enzymes for saccharification of cellulose or hemicelluloses, as yields are otherwise too low (Yang and Wyman, 2008). These pretreatments can be mechanical, chemical, thermochemical, and/or biological in nature, and currently represent some of the most costly steps in the lignocellulosic biorefining process (Mosier et al., 2005). Pretreatment methods that overcome the recalcitrance of lignocellulosic biomass and produce high sugar yields are needed before the cost-efficient production of renewable biofuels from lignocellulosic biomass can be accomplished (Dale, 2008; Wyman, 2008).

There is no consensus about the exact requirements for effective pretreatment. As a result, development of pretreatment technologies, selection of operating conditions, and design of pretreatment equipment is often a trial-and-error, empirically driven process (Wyman et al., 2005). Several structural and compositional attributes of biomass are thought to influence the enzymatic hydrolysis of cellulose to glucose including cellulose crystallinity (Chen et al., 2007b), presence of lignin (Selig et al., 2007), hemicellulose chemistry (Robinson et al., 2003), and the presence of acetyl groups (Zhu et al., 2008). Pretreatment is typically accomplished with technologies derived from the pulp and paper industry such as dilute acids [ $\mathrm{HCl}$ (Das et al., 2004), $\mathrm{H}_{2} \mathrm{SO}_{4}$ (Lloyd and Wyman, 2005; Yat et al., 2008)], ammonia recycle percolation (Kim and Lee, 2005), explosive 
decompression (Dekker, 1987), hot water (Liu and Wyman, 2005), lime (Chang et al., 2001), ammonia fiber explosion (Murnen et al., 2007), and organic solvents (Likon and Perdih, 1994). Pretreatment processes that increase the surface area accessible to water (largely excluded due to the packing of cellulose fibrils) and provide more accessible enzyme binding sites will thus substantially increase glucose and xylose yields (Bradshaw et al., 2007). These factors underline the importance of developing a pretreatment process that (a) converts the initial lignocellulosic material into an easily hydrolysable format and (b) does not produce any degradation products (Chen et al., 2007a) or inhibitory compounds that will negatively impact the downstream processing of that treated biomass into biofuels (Berson et al., 2006).

Promising new pretreatment approaches, such as biomass solubilization using ionic liquids (Dorn et al., 2008; Swatloski et al., 2002), need further exploration before implementation. Ionic liquids have been shown to be very effective in solubilizing crystalline cellulose (Zhao et al., 2009) and enhancing the rates of subsequent saccharification (Dadi et al., 2006). There have also been reports demonstrating the applicability of this technique in the processing of biomass (Fort et al., 2007; Xie et al., 2007). For instance, there is a recent report of pretreating maple wood flour with a variety of ionic liquids that produced an enhancement of cellulase saccharification yields due to the extraction of lignin (Lee et al., 2009).

While chemical pretreatment has been employed for several decades within the pulp and paper industry, a detailed cellular level understanding of the pretreatment process is lacking due in part to complexity of the biomass composition and structure, as well as interference from traditional staining, embedding, and processing chemicals that can sometimes alter the material under study. Here, we report an approach to spatially map cellulose and lignin in intact plant cell walls of switchgrass without the need for chemical or immunological labeling as a means to visualize the cellulose and lignin distribution in biomass. We evaluated the ability of an ionic liquid (1-n-ethyl-3methylimidazolium acetate (Kosan et al., 2008; Lee et al., 2009), referred to as EmimAc in the rest of this paper) to solubilize switchgrass, a leading candidate for national energy crop production (Sarath et al., 2008), and its ability to fractionate biomass into its major components (cellulose, hemicellulose, and lignin). This ionic liquid was selected due to its ready rejection of dissolved cellulose by the addition of an anti-solvent, such as water or ethanol, by a solutedisplacement mechanism (Zhu et al., 2006). While this process is ideal for simple cellulose systems, the disposition of the hemicellulose and lignin extracted via this technique from switchgrass into the ionic liquid is not currently known. As a point of comparison, it is reported that lignin from woody biomass is highly soluble in certain ionic liquids, and that after polysaccharide recovery the majority of the wood lignin remains solubilized in the ionic liquid (Fort et al., 2007).

\section{Materials and Methods}

\section{Sample Preparation}

Switchgrass (Panicum virgatum) stem pieces, provided by the laboratory of Dr. Ken Vogel, were thoroughly washed with water and embedded in OCT embedding medium (Miles Laboratories, Inc., Elkhart, IN) for a half hour and frozen. These samples were part of a well-characterized cultivar of switchgrass, and a full compositional analysis of this material is available elsewhere (Dien et al., 2006). Fifty micrometers of thick sections were collected on coverslips using a vibratome for sectioning. These sections were then rinsed with de-ionized water carefully to prevent curling and warping. For dynamic studies with ionic liquid, $400 \mu \mathrm{L}$ of 1 ethyl-3-methylimidazolium acetate, purchased from Sigma Aldrich (St. Louis, MO) and used as received, was placed on sectioned switchgrass stems and placed in a preheated oven at $120^{\circ} \mathrm{C}$ and removed at $5 \mathrm{~min}$ intervals.

\section{Laser Confocal Fluorescence Microscopy}

Microtomed switchgrass sections were imaged with a Zeiss LSM 510 confocal system mounted on a Zeiss Axiovert 100 microscope. A $405 \mathrm{~nm}$ Diode laser and a $543 \mathrm{~nm}$ Helium-Neon laser were used for sequential excitation and the spectra were acquired with a meta detector over a 411$743 \mathrm{~nm}$ range. Multi-track image acquisition techniques were used to minimize channel cross talk. For spectral unmixing, model lignin and lignin derived from switchgrass were used to subtract lignin contributions. Cellulose regeneration was visualized by spectral tomography along the $Z$-axis. Spectrum from each pixel in the images were analyzed and classified according to unique variance in the fluorescence emission patterns.

\section{Biomass Spectroscopy}

Attenuated total reflection-Fourier Transform Infrared Spectroscopy (ATR-FTIR) was conducted using a Bruker Optics Alpha system with a built-in diamond ATR. For bulk IL pretreatment studies, switchgrass was analyzed before ionic liquid pretreatment and after cellulose regeneration with water as anti-solvent. Air and ionic liquid solutions were used as backgrounds, respectively, for before and after IL pretreated/regenerated samples. Spectra shown are averages of 64 scans with $4 \mathrm{~cm}^{-1}$ spectral resolution over a $850-3,700 \mathrm{~cm}^{-1}$ range. Baseline correction was conducted using a rubber band correction method that involves stretching a line between spectrum endpoints that follows the spectrum minima.

\section{Scanning Electron Microscopy and XRD}

SEM was performed using a Hitachi 4500 on samples that were dropcast on double sided copper tape on precut silicon 
wafers and sputtered with approximately $30 \AA$ of $\mathrm{Au} / \mathrm{Pd}$. Images shown were acquired with $15 \mathrm{kV}$ accelerating voltages. X-ray powder diffraction patterns were obtained with a Scintag diffractometer on switchgrass samples deposited on double sided tape on microscope slides. Scans were collected at $45 \mathrm{kV}$ and $40 \mathrm{~mA}$ with a step size of $0.02^{\circ}$ every $0.5 \mathrm{~s}$.

\section{Sugar Assay}

Enzymatic conversion of untreated and IL pretreated and regenerated switchgrass to reducing sugars was accomplished using a Tichoderma reesei cellulase cocktail from Worthington Biochemical Corporation (Lakewood, NJ). The reported cellulase activity from the vendor of this cocktail is $55 \mathrm{FPU} / \mathrm{g}$. Cellulase at $50 \mu \mathrm{g} / \mathrm{mL}$ enzyme loading was used to hydrolyze the recovered and intact biomass (loaded at $17 \mathrm{mg} / \mathrm{mL}$ ) at $50^{\circ} \mathrm{C}$ in $50 \mathrm{mM}$ sodium citrate buffered at $\mathrm{pH} 4.8$. The solutions were mixed and heated using a temperature controlled shaking incubator. Sugar yields were measured using a dinitrosalicylic acid (DNS) assay (Breuil and Saddler, 1985) with D-glucose as the internal standard. Both untreated switchgrass and regenerated switchgrass after ethyl methyl imidazolium acetate $\left(\right.$ EmimAc) pretreatment $\left(120^{\circ} \mathrm{C}\right.$ for $\left.3 \mathrm{~h}\right)$ were run concurrently to avoid any potential errors in sugar yield associated with temperature and time differences.

\section{Results and Discussion}

Laser scanning confocal microscopy was employed to investigate lignin distribution in pristine microtomed and hand-sectioned switchgrass stems. Lignin is a complex heteropolymer with strong auto-fluorescence in the visible as well as far-IR regions (De Micco and Aronne, 2007). The chemical nature and relative amounts of lignin varies from biomass to biomass and within biomass samples as a function of location and lifecycle. Prior to ionic liquid pretreatment, spatial mapping of cellulose was accomplished by difference mapping of lignin distribution using intrinsic lignin auto-fluorescence in the sectioned biomass tissue and within the cell wall. Wavelength coded images were generated (Supplementary Information) providing diffraction limited high-resolution lignin mapping in switchgrass stems (Fig. 1). This produced a complete view of location and relative concentration (intensity) of lignin in $50 \mu \mathrm{m}$ thick stem sections (Fig. 1a). As expected, the amount of lignin was tissue specific, with the amount of lignin polymers as much as $2.5-3$ times more in middle lamella and cell corners as compared to secondary cell walls (Fig. 1a).

Linear unmixing from the wavelength coded original $405 \mathrm{~nm}$ confocal images of switchgrass stem section was accomplished via spectral subtraction of individual lignin fluorescence contributions. These included Klason, acid insoluble and acid soluble lignin signatures that are derived from switchgrass by standard lab procedures (Schwanninger and Hinterstoisser, 2006). This methodology generated the cellulose distribution/mapping observed in the switchgrass stem section (Fig. 1b). This analysis showed faint fluorescence due to pectin and other proteins present in the cell wall around the cellulose fibers. In these spectrally subtracted images, as expected, the cell corner and middle lamella appear dark. This result confirms the successful operation of this de-convolution algorithm routine for lignin subtraction (Fig. 1b). While not at the nanoscale, this routine still provides clear distinction between cellulose and lignin. Distinguishing between the closely related fluorescent and non-fluorescent cellulose and hemicellulose species by fluorescence-based techniques is difficult, and confocal Raman spectroscopic imaging may be better suited for chemical mapping of biomass polymers.

Trace amounts of lignin located within the parenchyma tissues typically present in grasses were easily detected using lignin auto-fluorescence. Fluorescence emission spectra fall into three distinct classes, which may represent the p-hydroxyphenyl $(\mathrm{H})$, guiacyl $(\mathrm{G})$, and syringyl (S) families of lignins. A representative spectrum of these individual components is shown in Figure 1c. The fluorescence lifetime decay curves exhibit contributions from at least three different species, also suggesting the presence of $\mathrm{H}, \mathrm{G}$, and $\mathrm{S}$ lignins. More details may be obtained by de-convolution of the spectra through Gaussian and Lorentzian curve fitting; however this was not undertaken in the present work.

Further details of the distribution of lignin, and the different morphologies as a function of position, within the switchgrass cell walls is given in Figure 2. This series of confocal fluorescence images show the junction formed by six parenchyma cells. Emission intensity clearly demonstrates greater lignin accumulation in middle lamella (Fig. 2a) and the cell corner (Fig. 2b). Inset showing cell wall with lignin variation in secondary cell walls (Fig. 2c) and, lignin rich sclerenchyma cell near the epidermis (Fig. 2d).

A series of time course images of ionic liquid pretreated switchgrass sections show remarkable details of the swelling of the switchgrass cell walls as compared to the initial intact material (Fig. 3a). Pretreatment with EmimAc resulted in swelling of the cell wall by a factor of $8 \times$ within $10 \mathrm{~min}$ of pretreatment in all samples (Fig. 3b). This swelling may be a result of breaking the inter- and intramolecular hydrogen bonding responsible for the rigid and highly compact crystalline cellulose polymer structure within biomass. The highly polar ionic liquid EmimAc may disrupt the hydrogen bonding interactions in biomass due to interactions between the ionic liquid anion and hydroxyl group hydrogen atoms within the biomass. Remsing et al. (2006) recently proposed a mechanism, based on NMR results, in which hydrogen bonding between the carbohydrate hydroxyl protons and the ionic liquid anions are the critical factors in the ionic liquid solubilization process.

As discussed earlier, although cellulose solubilization using different ionic liquids has been clearly demonstrated, 

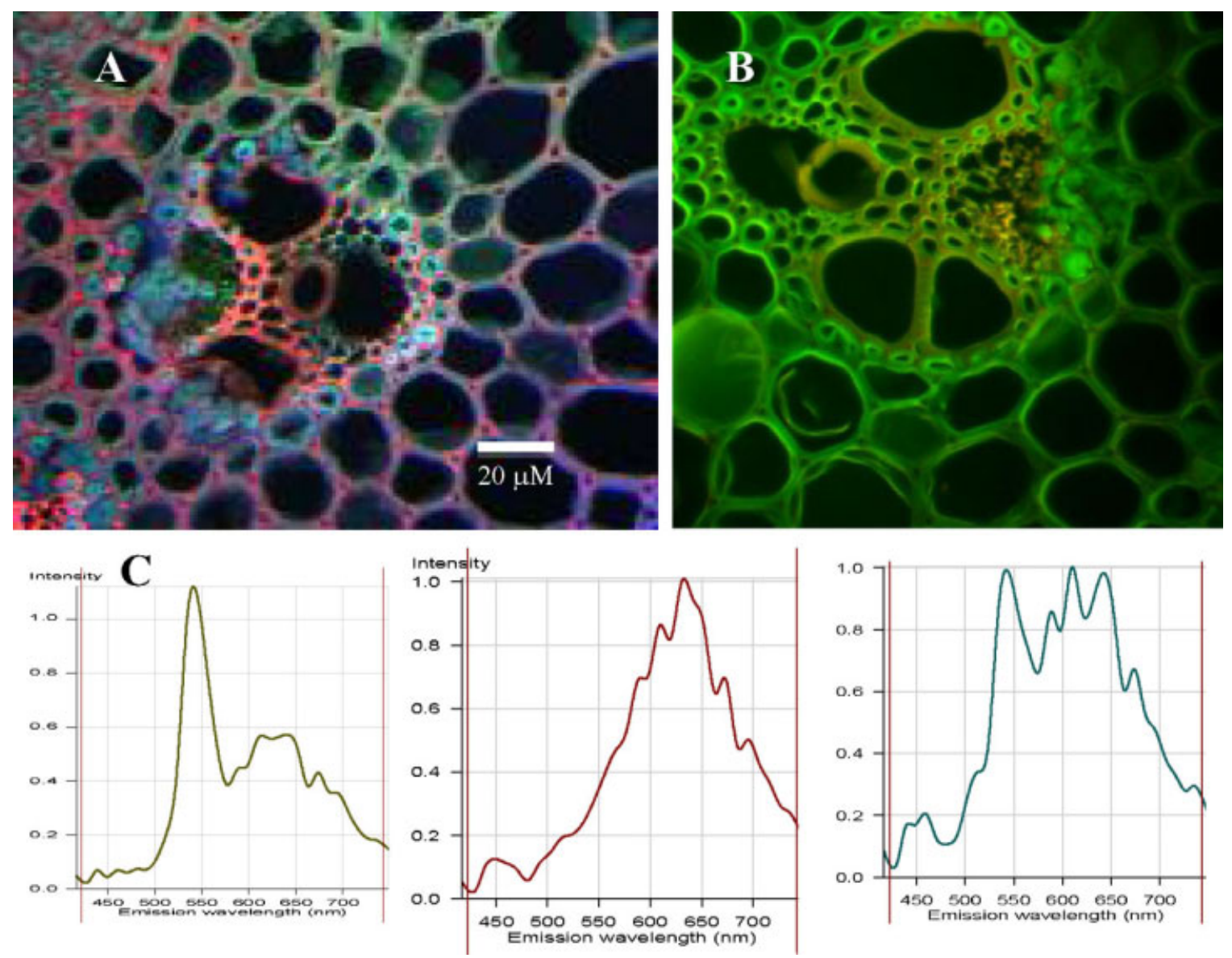

Figure 1. Optical tomography and spatial mapping of lignin and cellulose in section of switchgrass. a: Fluorescence emission image of switchgrass stem showing lignin fluorophore distribution and concentration variation in the switchgrass stem tissue and cell wall. Highly conjugated lignin polymer exhibit intrinsic fluorescence shown here after excitation with $405 \mathrm{~nm}$ diode laser. b: Wavelength coded confocal fluorescence image and cellulose distribution after linear un-mixing using lignin extracted from switchgrass and model monolignols. Typical fluorescence emission spectra of switchgrass stem depicting multi-component nature of cell wall lignins. The three spectra may represent the $p$-hydroxyphenyl $(\mathrm{H})$, guiacyl (G), and syringyl (S) families of lignins.

the disposition of lignin and hemicellulose from the cell walls of switchgrass that is also solubilized during EmimAc pretreatment has not been directly observed during the pretreatment process. Our in situ ionic liquid pretreatment data clearly demonstrate that EmimAc is able to completely solubilize both the cellulose and lignin in switchgrass. This is in contrast to a recent report that found that EmimAc preferentially extracted lignin from maple wood flour (Lee et al., 2009). The lignin-rich sclerenchyma and middle lamella (Fig. 4a) in plant tissues disintegrate immediately and simultaneously as primary and secondary cell walls start separating from the middle lamella (Fig. 4b). Within 30 $50 \mathrm{~min}$ of pretreatment at $120^{\circ} \mathrm{C}$ (Fig. 4c), intact stem sections formed a very viscous solution, and complete solubilization was accomplished after 2.5-3 h (Fig. 4d). Optical tomography provided confirmation of complete dissolution. In a simultaneous separate bulk experiment performed in a scintillation vial, complete biomass dissolution was also accomplished leading to viscous amber colored solution, indicating solvation of the lignin polymer along with cellulose and hemicellulose.

In addition to completely solubilizing the switchgrass, the addition of water to EmimAc after pretreatment results in the precipitation of polysaccharides for downstream processing. The extent of lignin de-polymerization and interaction of lignin with anti-solvent, ionic liquid, or cellulose will dictate the purity of the regenerated cellulose for downstream saccharification and sugar yield, and most importantly, enable the establishing of protocols for recycling the ionic liquid in a closed loop system. The exact chemical composition of these regenerated fibers from solubilized switchgrass, including their lignin, cellulose, and hemicellulose content, is currently unknown. After ionic liquid pretreatment, the solubilized switchgrass solution was examined during cellulose regeneration with water (Fig. 5). The pretreated and solubilized switchgrass (Fig. 5a) has a poorly defined morphology consistent with the lack of any coherent structure and the observation that all major 


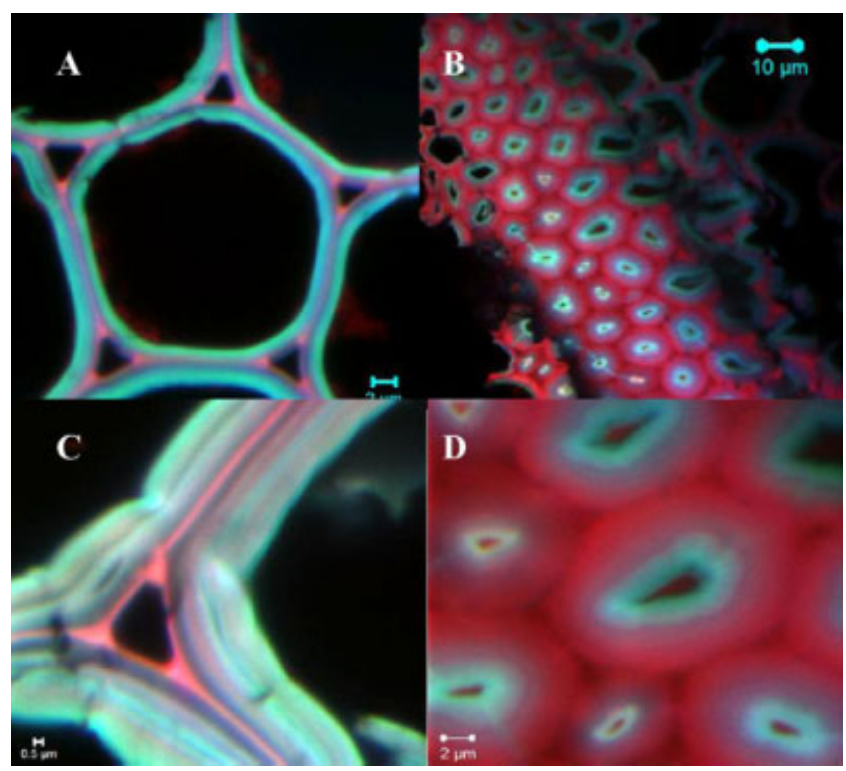

Figure 2. Confocal fluorescence image showing cell wall from junction of six parenchyma cells. Emission intensity clearly demonstrates greater lignin accumulation in middle lamella (a) and cell corner (b). Inset showing cell wall with lignin variation in secondary cell walls (c) and, lignin rich sclerenchyma cell near the epidermis (d).

components found in the plant cell walls are solubilized in the EmimAc. After addition of water to this solution, it is observed that fibrous structures are formed $(300-500 \mathrm{mM}$ long), and that this regenerated product rejects lignin during this process as evidenced by the appearance of the nonfluorescent fibers that are clearly visible in the fluorescent lignin-ionic liquid-water solution (Fig. 5b).

To confirm the rejection of lignin by this recovery process, ATR-FTIR was employed to track composition. ATR-FTIR of a model micro-crystalline cellulose polymer (Avicel PH 101), switchgrass and regenerated cellulose (after addition of
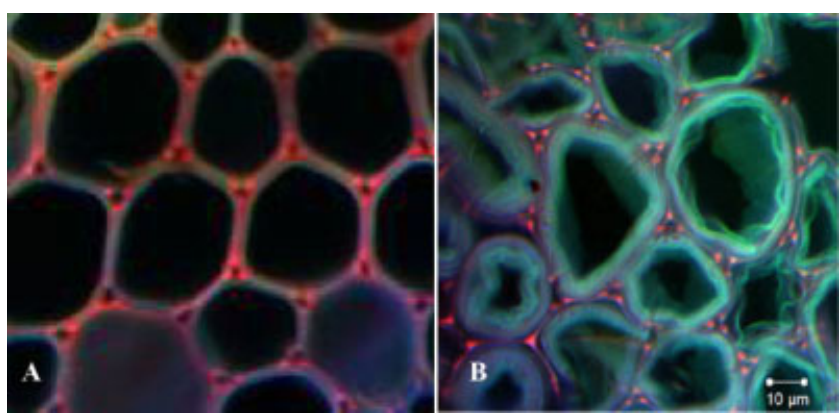

Figure 3. Confocal fluorescence images of parenchyma cell wall, (a) before pretreatment and (b) swollen cell wall after 10 min pretreatment with ethyl methyl imidazolium acetate at $120^{\circ} \mathrm{C}$. Highly polar ionic liquids are very effective in solvating cellulosic biomasses due to hydrogen bond formation between hydroxyl group hydrogen atoms in the cellulose and ionic liquid anions.
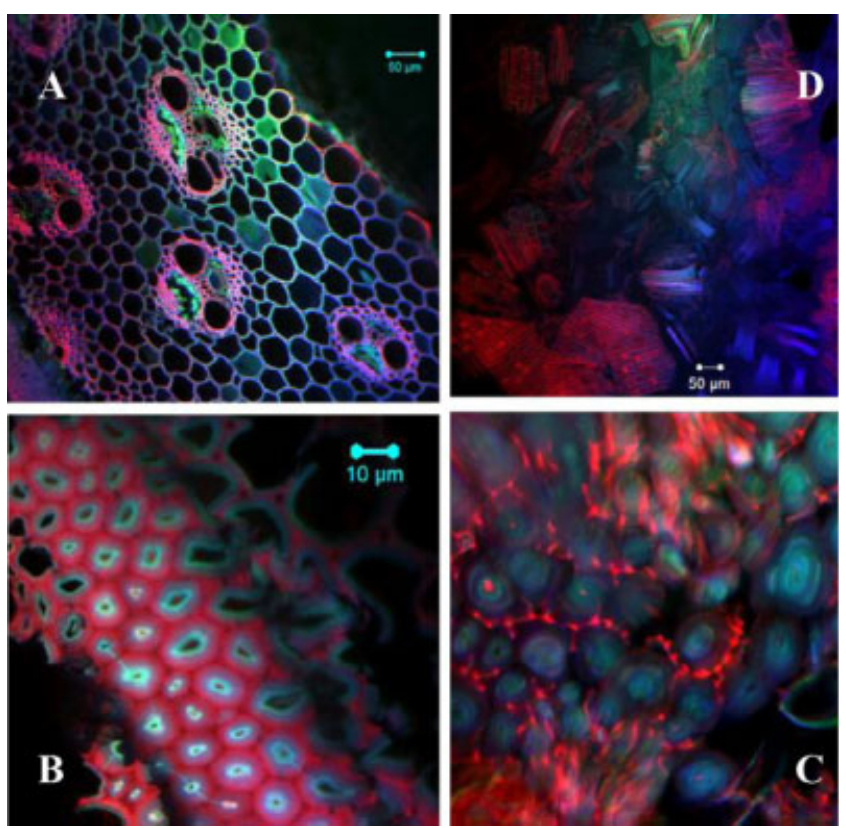

Figure 4. In situ dynamic study of switchgrass dissolution in ethyl methyl imidazolium acetate. Confocal fluorescence images of switchgrass stem section before pretreatment (a), and after 20 (b) and 50 (c) min of pretreatment. Complete breakdown of organized plant cell wall structure (d) is observed after $2 \mathrm{~h}$.

water) shows very intense absorbance at $3,305,3,405$, and $3,340-3,375 \mathrm{~cm}^{-1}$ that is associated with $\mathrm{O}(3) \mathrm{H}-\mathrm{O}(5)$ intramolecular stretching. Intramolecular hydrogen bonding (crystallinity index, $\mathrm{CI}$ ), inferred from absorbance peak ratio at $1,427 \mathrm{~cm}^{-1}\left(\mathrm{CH}_{2}\right.$ bending mode $)$ to $895 \mathrm{~cm}^{-1}$ (deformation of anomeric $\mathrm{CH}$ ), decreased in ionic liquid regenerated cellulose (Fig. 4). In addition to ATR-FTIR, powder X-ray diffraction measurements (Supplementary Information) also confirm that regenerated cellulose after ionic liquid pretreatment was amorphous. The typical crystalline peaks at $2 \mathrm{q}$ of $23^{\circ}$ (due to 002 crystalline plane)
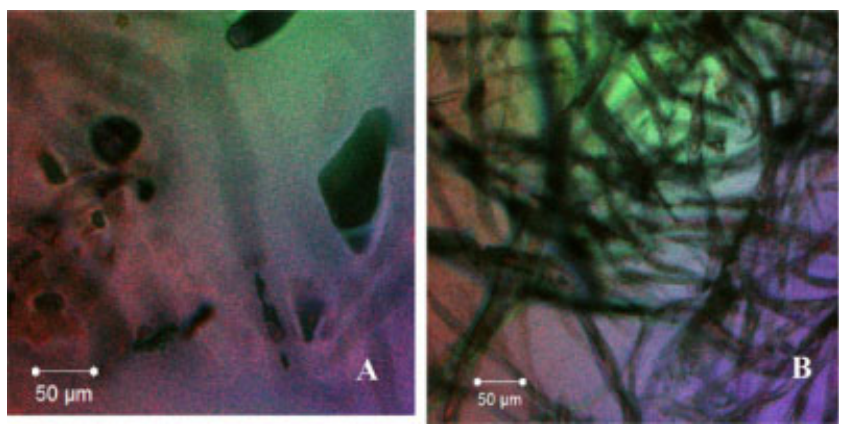

Figure 5. In situ examination of cellulose regeneration. Confocal optical slice showing cellulose regeneration after anti-solvent (water) addition into ionic liquid solubilized switchgrass (a). Regenerated non-fluorescent cellulose (b) appears to reject lignin and appear as dark fibers in the lignin-ionic liquid fluorescent solution. 


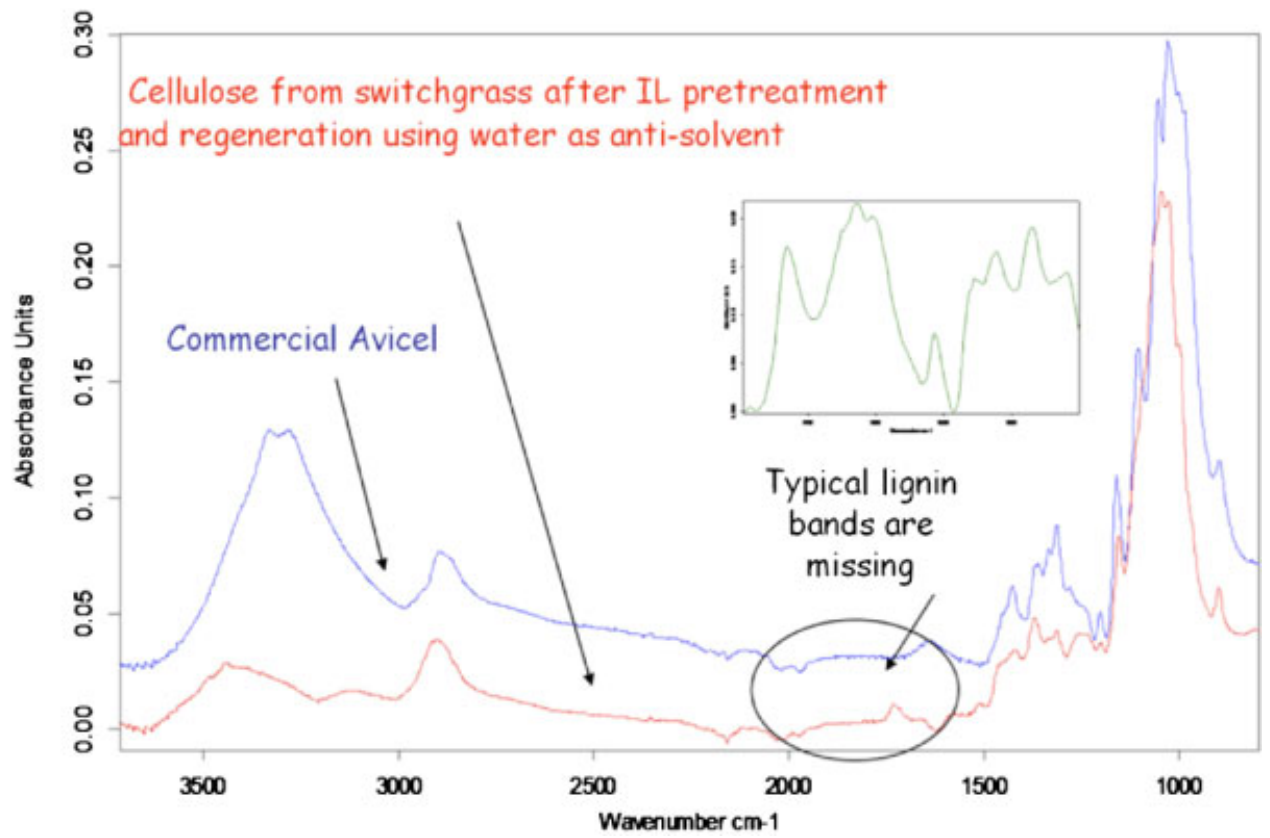

Figure 6. Compositional analysis of regenerated cellulose. ATR-FTIR spectra of recovered product from ionic liquid dissolved switchgrass after water addition (red curve) and comparison with commercial model cellulose (blue curve). Cellulose bands $\left(1,098\right.$ and $\left.2,900 \mathrm{~cm}^{-1}\right)$ are present in both spectra with $3,305-3,405 \mathrm{~cm}^{-1}$ band intensities significantly lower in regenerated cellulose illustrating considerable weakening of inter and intramolecular hydrogen bonding after ionic liquid pretreatment. Typical lignin bands from aromatic phenyl $\mathrm{C}=\mathrm{C}\left(1,605\right.$ and $\left.1,515 \mathrm{~cm}^{-1}\right)$ are missing which are clearly present in untreated switchgrass spectra (inset).

present in original biomass diffraction pattern are weakened and shifted to $21^{\circ}$. The peak at $2 \mathrm{q}$ of $15^{\circ}$ is missing in regenerated cellulose diffraction pattern after ionic liquid pretreatment.

Chemical fingerprinting of the recovered fibers, when compared with commercially available cellulose (Avicel PH 101) and switchgrass, provided further confirmation of lignin dissociation from the polysaccharides during pretreatment. Fourier transform infrared spectrometry of regenerated fibers (Fig. 6) showed absence of lignin bands in $1,550-1,640 \mathrm{~cm}^{-1}$ range indicative of aromatic $\mathrm{C}=\mathrm{C}$ vibrations. In addition, comparison of scanning electron micrographs of untreated biomass and pretreated and regenerated fibers show complete unpacking of compact rod-like macro fiber bundles after pretreatment with loss of hierarchical structural ordering and significant differences in morphologies (Fig. 7). SEM micrographs of ionic liquid pretreated and regenerated cellulose (Fig. 7b) from switchgrass (Fig. 7a) appear significantly different from acid pretreated biomass. There was no evidence of micron scale lignin accumulation on cellulose fibers, confirming the ATR-FTIR data and the observation that covalent linkages between lignin and cellulose are disrupted. It appears that the EmimAc ionic liquid pretreatment effectively weakens the van der Waal's interaction between cell wall polymers. Since hemicellulose forms covalent linkages with lignin through ferulic acids and with cellulose via pectin, it cannot be concluded which linkages are disrupted during ionic
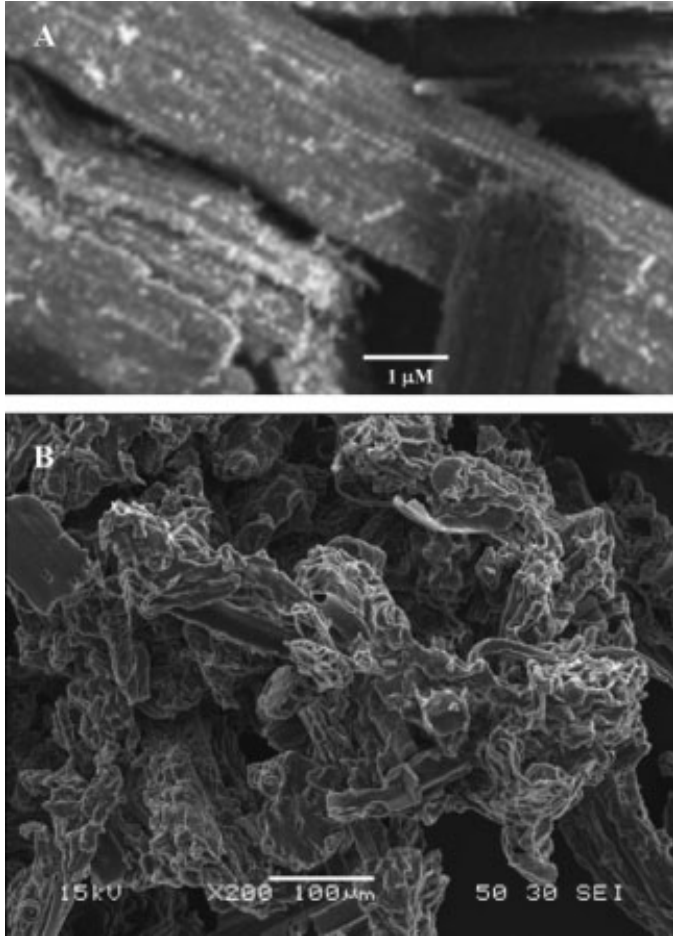

Figure 7. SEM micrographs of (a) untreated and (b) ionic liquid pretreated and recovered fibers from switchgrass. 
liquid pretreatment that result in formation of lignindeficient regenerated cellulose.

The loss of intra- and intermolecular hydrogen bonding resulting in amorphous cellulose provide enhanced surface area leading to better enzyme accessibility and increased binding sites in regenerated cellulose fibers. Our DNS assay data using $T$. reesei commercial cellulase cocktail show that after $24 \mathrm{~h} 72.5 \%$ of switchgrass is converted to sugar for the treated switchgrass, compared to $16.5 \%$ for the untreated switchgrass. Both reactions are carried out using the same enzyme loading level $(50 \mu \mathrm{g} / \mathrm{mL})$. In addition, the maximum theoretical yield of glucose was achieved for the ionic liquid pretreated switchgrass after $30 \mathrm{~h}$ of enzymatic hydrolysis. It is yet to be established if ionic liquid pretreatment generates any inhibitory complexes akin to acid pretreatment and if saccharification in the presence of a large amount of ionic liquid inhibits cellulase activity.

\section{Summary}

We have utilized the auto-fluorescence of plant cell walls to track the dynamic solubilization mechanisms during ionic liquid pretreatment of switchgrass. The ionic liquid was observed to quickly swell the secondary cell walls and completely solubilized the plant cell walls within $3 \mathrm{~h}$ of exposure at $120^{\circ} \mathrm{C}$. Recovery of pretreated product was realized through the addition of an anti-solvent. Upon addition of anti-solvent, fibers were observed to precipitate out of solution that possessed minimal auto-fluorescence, indicating that lignin remained in solution and that disruption of the lignin-carbohydrate complex had occurred. This loss of lignin observation was reinforced by ATR-FTIR measurements of the recovered polysaccharide product. The pretreated material was efficiently hydrolyzed into glucose with a commercial cellulase cocktail, indicating that this approach was very effective in disrupting the recalcitrant nature of the initial biomass to subsequent processing that liberate the fermentable sugars.

The insight gained into the ionic liquid pretreatment of switchgrass by this technique of label-free visualization and mapping will facilitate the rapid screening of a wide range of ionic liquids. This approach can be used for biomass of different chemical compositions and assist in determining the impact of genetically engineered feedstocks to enable the efficient deconstruction of lignocellulosics. In addition, by utilizing this in situ technique, the development and selection of pretreatment conditions for the selective solubilization and fractionation of either polysaccharides or lignin could be tailored for the development of costeffective biomass pretreatments with enhanced saccharification yields.

This work was part of the DOE Joint BioEnergy Institute (http:// www.jbei.org) supported by the U.S. Department of Energy, Office of Science, Office of Biological and Environmental Research, through contract DE-AC02-05CH11231 between Lawrence Berkeley National Laboratory and the U.S. Department of Energy.

\section{References}

Berson RE, Young JS, Hanley TR. 2006. Reintroduced solids increase inhibitor levels in a pretreated corn stover hydrolysate. Appl Biochem Biotechnol 129-132:612-620.

Bradshaw TC, Alizadeh H, Teymouri F, Balan V, Dale BE. 2007. Ammonia fiber expansion pretreatment and enzymatic hydrolysis on two different growth stages of reed canarygrass. Appl Biochem Biotechnol 137-140: 395-405.

Breuil C, Saddler JN. 1985. Comparison of the 3,5-dinitrosalicylic acid and Nelson-Somogyi methods of assaying for reducing sugars and determining cellulase activity. Enzyme Microb Technol 7(7):327-332.

Chang VS, Nagwani M, Kim CH, Holtzapple MT. 2001. Oxidative lime pretreatment of high-lignin biomass: Poplar wood and newspaper. Appl Biochem Biotechnol 94(1):1-28.

Chen SF, Mowery RA, Chambliss CK, van Walsum GP. 2007a. Pseudo reaction kinetics of organic degradation products in dilute-acid-catalyzed corn stover pretreatment hydrolysates. Biotechnol Bioeng 98(6):11351145.

Chen Y, Stipanovic AJ, Winter WT, Wilson DB, Kim YJ. 2007b. Effect of digestion by pure cellulases on crystallinity and average chain length for bacterial and microcrystalline celluloses. Cellulose 14(4):283-293.

Dadi AP, Varanasi S, Schall CA. 2006. Enhancement of cellulose saccharification kinetics using an ionic liquid pretreatment step. Biotechnol Bioeng 95(5):904-910.

Dale BE. 2008. Biofuels: Thinking clearly about the issues. J Agric Food Chem 56(11):3885-3891.

Das P, Ganesh A, Wangikar P. 2004. Influence of pretreatment for deashing of sugarcane bagasse on pyrolysis products. Biomass Bioenergy 27(5): 445-457.

De Micco V, Aronne G. 2007. Combined histochemistry and autofluorescence for identifying lignin distribution in cell walls. Biotechnol Histochem 82(4-5):209-216.

Dekker RFH. 1987. The utilization of autohydrolysis-exploded hardwood (Eucalyptus regnans) and softwood (Pinus radiata) sawdust for the production of cellulolytic enzymes and fermentable substrates. Biocatalysis 1(1):63-75.

Demirbas A. 2008. Biofuels sources, biofuel policy, biofuel economy and global biofuel projections. Energy Conversion Manage 49:2106-2116.

Dien BS, Jung HG, Vogel KP, Casler MD, Lamb JFS, Weimer PJ, Iten L, Mitchell RB, Sarath G. 2006. Chemical composition and response to dilute-acid pretreatment and enzymatic saccharication of alfalfa, reed canarygrass, and switchgrass. Biomass Bioenergy 2006. 30(10):880-891.

Dorn S, Wendler F, Meister F, Heinze T. 2008. Interactions of ionic liquids with polysaccharides-7: Thermal stability of cellulose in ionic liquids and N-methylmorpholine-N-oxide. Macromol Mat Eng 293(11):907-913.

Fort DA, Remsing RC, Swatloski RP, Moyna P, Moyna G, Rogers RD. 2007. Can ionic liquids dissolve wood? Processing and analysis of lignocellulosic materials with 1-n-butyl-3-methylimidazolium chloride. Green Chem 9(1):63-69.

Gallezot P. 2008. Catalytic conversion of biomass: Challenges and issues. ChemSusChem 1(8-9):734-737.

Gomez LD, Steele-King CG, McQueen-Mason SJ. 2008. Sustainable liquid biofuels from biomass: The writing's on the walls. New Phytol 178(3): 473-485.

Kim TH, Lee YY. 2005. Pretreatment and fractionation of corn stover by ammonia recycle percolation process. Biores Technol 96(18):20072013.

Kosan B, Michels C, Meister F. 2008. Dissolution and forming of cellulose with ionic liquids. Cellulose 15(1):59-66.

Lee HS, Doherty TV, Linhardt RJ, Dordick JS. 2009. Ionic liquid-mediated selective extraction of lignin from wood leading to enhanced enzymatic cellulose hydrolysis. Biotechnol Bioeng 102(5):1368-1376.

Likon M, Perdih A. 1994. Lignocellulose delignification in organic solvents. Acta Chim Slov 41(3):353-374.

Liu C, Wyman CE. 2005. Partial flow of compressed-hot water through corn stover to enhance hemicellulose sugar recovery and enzymatic digestibility of cellulose. Biores Technol 96(18):1978-1985. 
Lloyd TA, Wyman CE. 2005. Combined sugar yields for dilute sulfuric acid pretreatment of corn stover followed by enzymatic hydrolysis of the remaining solids. Biores Technol 96(18):1967-1977.

Lynd LR, Laser MS, Bransby D, Dale BE, Davison B, Hamilton R, Himme M, Keller M, McMillan JD, Sheehan J, Wyman CE. 2008. How biotech can transform biofuels. Nat Biotechnol 26(2):169-172.

Mosier N, Wyman C, Dale B, Elander R, Lee YY, Holtzapple M, Ladisch M. 2005. Features of promising technologies for pretreatment of lignocellulosic biomass. Biores Technol 96(6):673-686.

Murnen HK, Balan V, Chundawat SPS, Bals B, Da Costa Sousa L, Dale BE. 2007. Optimization of ammonia fiber expansion (AFEX) pretreatment and enzymatic hydrolysis of miscanthus $\mathrm{x}$ giganteus to fermentable sugars. Biotechnol Progress 23(4):846-850.

Remsing RC, Swatloski RP, Rogers RD, Moyna G. 2006. Mechanism of cellulose dissolution in the ionic liquid 1-n-butyl-3-methylimidazolium chloride: A $13 \mathrm{C}$ and 35/37Cl NMR relaxation study on model systems. Chem Commun 12:1271-1273.

Robinson J, Keating JD, Mansfield SD, Saddler JN. 2003. The fermentability of concentrated softwood-derived hemicellulose fractions with and without supplemental cellulose hydrolysates. Enzyme Microb Technol 33(6):757-765.

Sarath G, Mitchell RB, Sattler SE, Funnell D, Pedersen JF, Graybosch RA, Vogel KP. 2008. Opportunities and roadblocks in utilizing forages and small grains for liquid fuels. J Ind Microbiol Biotechnol 35(5):343354.

Schwanninger M, Hinterstoisser B. 2006. Klason lignin: Modifications to improve the precision of the standardized determination. Holzforschung 56(2):161-166.

Selig MJ, Viamajala S, Decker SR, Tucker MP, Himmel ME, Vinzant TB. 2007. Deposition of lignin droplets produced during dilute acid pre- treatment of maize stems retards enzymatic hydrolysis of cellulose. Biotechnol Progress 23(6):1333-1339.

Sierra R, Smith A, Granda C, Holtzapple MT. 2008. Producing fuels and chemicals from lignocellulosic biomass. Chem Eng Prog 104(8):S10-S18.

Simmons BA, Loque D, Blanch HW. 2008. Next-generation biomass feedstocks for biofuel production. Gen Biol 9:242.

Swatloski RP, Spear SK, Holbrey JD, Rogers RD. 2002. Dissolution of cellulose with ionic liquids. J Am Chem Soc 124(18):4974-4975.

Wyman CE. 2008. Cellulosic ethanol: A unique sustainable liquid transportation fuel. MRS Bull 33(4):381-383.

Wyman CE, Dale BE, Elander RT, Holtzapple M, Ladisch MR, Lee YY. 2005. Coordinated development of leading biomass pretreatment technologies. Biores Technol 96(18):1959-1966.

Xie H, King A, Kilpelainen I, Granstrom M, Argyropoulos DS. 2007. Thorough chemical modification of wood-based lignocellulosic materials in ionic liquids. Biomacromolecules 8(12):3740-3748.

Yang B, Wyman CE. 2008. Pretreatment: The key to unlocking low-cost cellulosic ethanol. Biofuels Bioproducts Biorefining 2(1):26-40.

Yat SC, Berger A, Shonnard DR. 2008. Kinetic characterization for dilute sulfuric acid hydrolysis of timber varieties and switchgrass. Biores Technol 99(9):3855-3863.

Zhao H, Jones CL, Baker GA, Xia S, Olubajo O, Person VN. 2009. Regenerating cellulose from ionic liquids for an accelerated enzymatic hydrolysis. J Biotechnol 139(1):47-54.

Zhu S, Wu Y, Chen Q, Yu Z, Wang C, Jin S, Ding Y, Wu G. 2006. Dissolution of cellulose with ionic liquids and its application: A minireview. Green Chem 8(4):325-327.

Zhu L, O’Dwyer JP, Chang VS, Granda CB, Holtzapple MT. 2008. Structural features affecting biomass enzymatic digestibility. Biores Technol 99(9):3817-3828. 